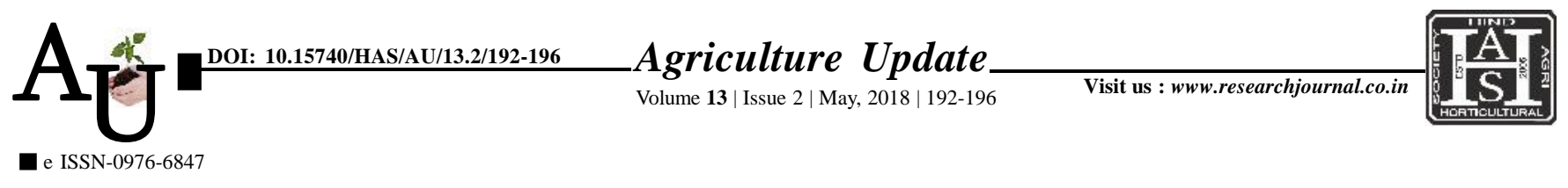

\title{
Rеввавсн автіске: Participation of tribal youth in agricultural activities
}

\author{
T.P. Bharath Kumar, M.S. Nataraju and M.T. Lakshminarayan
}

Article Chronicle : Received :

09.03.2018;

Revised :

01.04.2018;

Accepted :

14.04.2018

\section{KEY Words :}

Youth, Participation, Agricultural activities
SUMMARY : The present study was carried out in two districts of Karnataka State during 2017-2018 to analyze the participation of tribal youth in agricultural activities. One hundred and sixty tribal youth were interviewed using a pre-tested interview schedule. The results revealed that a large number of tribal youth $(40.63 \%)$ belong to high category of overall participation in agricultural activities, whereas 38.13 and 21.25 per cent of the tribal youth belong to low and medium level of overall participation in agricultural activities. Further, it was found that there exist no significant difference between Soliga and Kuruba tribal youth with respect to their participation in agricultural activities.

How to cite this article : Kumar, T.P. Bharath, Nataraju, M.S. and Lakshminarayan, M.T. (2018). Participation of tribal youth in agricultural activities. Agric. Update, 13(2): 192-196; DOI : 10.15740/HAS/AU/13.2/192-196. Copyright@2018: Hind Agri-Horticultural Society.
Author for correspondence :

\section{T.P. Bharath Kuma} Krishi Vigyan Kendra, Mudigere,

Chikkamagaluru

(Karnataka) India

See end of the article for authors' affiliations 